\title{
Footing and Speech Acts in the Qur'anic Dialogue of Allah and Iblīs: A Pragmatically Enhanced Approach
}

https://doi.org/10.33806/ijaes2000.21.2.5

\author{
Amir H. Y. Salama \\ Prince Sattam Bin Abdulaziz University, Saudi Arabia \\ Kafr El-Sheikh University, Egypt
}

\begin{abstract}
This study seeks to examine the interface potentially holding between footing and the speech acts performed in the main Qur'anic dialogue of Allah and Iblīs (Q15:32-43). The study utilizes a synthetic approach that combines two theoretical strands: (i) Erving Goffman's (1979, 1981) interaction model of footing as orchestrated by the speaker roles of animator, author, and principal; (ii) Searle's (1976) classification scheme of illocutionary acts and their felicity conditions. Crucially, the pragmatically enhanced footing analysis of the Qur'anic speech event that binds Allah and Iblis has demonstrated how the two participants perform illocutionary acts that determine their theologically felicitous speaker roles as animator, author, and/or principal. Five categories of illocutionary acts have been identified in the overall participation framework of the dialogue: expressives, directives, declarations, representatives, and commissives. Based on these categories, both Allah and Iblis have performed acts as authors, whose utterances are animated via the reportorial style of the Qur'anic text; further, the perlocutions of certain acts have manifested the discursive positions of each participant in a way that reflects his manipulating speaker role in the speech event.
\end{abstract}

Keywords: Allah, footing, Iblīs, principal, the Qur'an, speech acts

\section{Introduction}

One of the notable advances on earlier methods of investigating social interaction has been Erving Goffman's interaction model of "footing" $(1979,1981)$. The model has been presented as a method that can effectively explicate the participant's "alignment, or set, or stance, or posture, or projected self" in given speech situations, where a change in footing "implies change in the alignment we take up to ourselves and the others present as expressed in the way we manage the production and perception of an utterance" (Goffman 1981:128). Indeed, Goffman's model of footing departs from the traditional models of communication (e.g., Shannon and Weaver 1949); for, in the former, the message receiver should be substituted for the audience and their multiple roles in communication (Goffman 1981:131-134); and likewise, the sender, or the speaking individual, should not be viewed as being merely the discursively fixed "I," but rather as "speaking, explicitly or implicitly, in the name of "we"" (1981:145). Crucially, the speaking individual has been argued by Goffman to assume different production-format aspects, viz. "animator," "author," and "principal" (see section 3). 
One of the most important critiques and developments of Goffman's model of "footing" is Levinson (1988). Partington (2003:49-53) reports two of the main points raised by Levinson in his critique of footing. First, Goffman's model fails to draw a pragmatic distinction between speech event and utterance event; second, having been designed to analyse face-to-face conversations, the model cannot adequately deal with other forms of talk. Indeed, Levinson's (1988) treatment of the analytic categories associated with footing has been confined to the scope of deictics. In his framework, Levinson (1988:170-174) developed the roles related to participants (speakers and hearers) in terms of the components of "participation," "transmission," "motive," "form," "address," "recipientship," and "channellinkage." Although such participant-related elements have proved analytically useful to the model of footing, they seem to be problematic; for these elements are so deictically centred that other essential pragmatic dimensions have been marginalized. More specifically, the pragmatic forces motivating both Goffman's and Levinson's participant elements to behave as interlocutors are not explained despite the fact that they may be inherent in the speech utterance, and, thus, help the analyst better understand the speech event itself.

Here, I argue, this problem may be resolved by connecting the footing model with the various illocutionary acts involved in the speech event at the level of speech utterance; thus, every utterance is likely to have an illocutionary act, whereby the analyst can explain both the role pragmatically performed by the participant and the effect this act may have on other participants in the speech event (see section 3). However, there remains another facet of the problem that lies with Goffman's footing: it has been designed to analyse only face-to-face conversations. Consequently, it can be assumed that virtually every new set of data is likely to entail the presence of modifications, and even additions, which should be methodologically brought to the model.

As shown in the coming section, Goffman's model of footing has been productively applied to various discursive domains such as education, media, and politics excluding religion, particularly those types of religious texts reckoned to be sacred or divine. The Qur'an is one such text, and it is taken here as a model for footing analysis. One theological fact about the main features of the Qur'an's dialogic discourse is its heavily reportorial style, i.e., all incidents and participants in the speech events are presented as being divinely reported; further, Abdul-Raof (2018:46) argues, Qur'anic discourse in general allows for the presence of highly performative speech acts with illocutionary or communicative force for a specific perlocutionary effect. Significantly, this perlocutionary effect derives mainly from the Islamic postulate that the Qur'an is reckoned to be "God's [Allah's] speech (kalām) or knowledge ('ilm), which are God's [Allah's] eternal attributes" (alĀjurrī 1983:75-76, cited in Abrahamov 2006:424). It can be said that such a postulate renders Qur'anic dialogues interesting in terms of the reporter's (Allah's) voice of absolute truth, especially if Allah Himself plays an actual role in these dialogues. Of course, this sets Qur'anic dialogues aside from comparable dialogues in literature, where authorial truth is far from being absolutist or radical to any given faith community. 
Thus, considering the two facets of the research problem outlined above and the data suggested for analysis, the present study hypothesizes that an analysis of the speech acts performed by Allah and Iblīs in the Qur'anic text and their potential corresponding speech roles (animator, author, and principal) may reveal significant shifts in the footing adopted by the two participants (Allah and Iblīs) in their main dialogue in the Qur'an (Q15:32-43); a dialogue that brings together the two participants as interlocutors committed to three types of act: (i) the participant's linguistic input in the dialogue (locution), (ii) the participant's performative intent of uttering the words (illocution), and (iii) the participants' pragmatic effect on each other in the speech events (perlocution). Upon the foregoing hypothesis, the following research question may arise: What are the main speaking roles adopted by the interlocutors in the main Qur'anic dialogue of Allah and Iblīs? In order for this question to be addressed, the following sub-questions need to be answered: (1) What are the participant-bound aspects uttered by both interlocutors at locution level? (2) How is each interlocutor's illocutionary acts performed? (3) What perlocutionary effects do these performed acts have on the speech event?

The above questions shed light on the significance of the current study's method that combines Goffman's model of footing and Searle's theory of speech acts. The data used for analysis is a single speech event with eleven Qur'anic verses that involve Allah and Iblīs as interlocutors (Q15:32-43). Although in the Qur'an there are other speech events with the same interlocutors (e.g., Q4:118-120; Q7:1218; Q17:61-65), the one selected here is relevant to the present context of research. The rationale for selecting this particular event is twofold. First, it is the lengthiest speech event including Allah and Iblīs in terms of the number of turns in the Qur'an, and thus offers the most exhaustive account of the topics relevant to the dialogue. Second, virtually all similar events reiterate the same speech acts performed by Allah and Iblīs, and therefore conducting analysis on such similar events is likely to replicate the same results.

For analytic purposes, the Arabic data, drawn from the Qur'anic text, is systematically represented in two ways. First, the Library of Congress transliteration system is utilized - with slight modifications - in the phonetic writing of Classical Arabic forms in the Roman alphabet. Second, an English translation of the verses under analysis is adopted for the sake of transferring the meaning potential of the verses to English. Among the many different English translations of the Qur'an, Yusuf Ali's (1934 [1983]) translation has been selected since it "preserves the source language long structure and conjunctions to maintain the flavour and meaning" of the original source text (Abdul-Raof 2001:18). At this point, it should be made clear that the English translation of the dialogue is not the actual target of analysis; rather, the Classical Arabic text drawn from the Qur'an is examined, and the English translation is used only as a facilitator for those who lack knowledge of Arabic. It should also be made explicit that, in terms of the current pragmatically enhanced analysis of footing, the same (pro-) nominal system and speech acts are maintained in the English translation; and in these respects there seem to be no discrepancies whatsoever between the Qur'anic source text in Arabic and the target text in English. 


\section{Literature review}

The research employing Goffman's (1981) model of footing has been conducted across different discursive domains, notably education, media, and politics. In the discursive domain of education, Wortham (1996) analysed five minutes of a class conversation, with a special focus on personal pronouns as one type of deictics; he concluded that personal pronouns index interactional alignment for the narrative events in classroom discourse; this has been proven by means of the methodological technique of "deictic mapping." Kristiansen (2017) defined and described Writing Aloud Voice (WAV) sequences as a change of footing that is utilized in formulation-bound hypothetical speech; she investigated a number of video recordings of the meetings of student projects. Kristiansen found that WAV sequences comprised, among other things, a "quotative construction" that projected a change of footing and an "existing device" that constituted a "return to previous footing" (Kristiansen 2017:49). Čekaite and Evaldsson (2019) explored the language of practices used in a linguistically heterogeneous group of children located in a regular monological preschool in Sweden, with Swedish serving as a lingua franca. The two authors demonstrated how footing shifts were used by children in a playful fashion to comment on misunderstandings in their own and others' language use, e.g., Kurdish dialects (Sorani and Kumanji).

In the media domain, footing shifts have been discussed in a number of significant studies. Examining television news interviews, Clayman (1992) demonstrated what he dubbed the "neutralistic" stance adopted by interviewers who shift their footing at some strategic points throughout the interview; for example, by embedding assertive and evaluative statements into questions, employing passive voice, or doing self-repair. Sandrelli (2017) investigated the footing shifts in audio and video data drawn from FOOTIE, a corpus of simultaneously interpreted football press conferences. Sandrelli found that such footing shifts, particularly those compared with the bilingual settings of face-to-face interpreting, showed that the interactants and their participation structure of the FOOTIE press conferences were highly complex (Sandrelli 2017:15).

Still in the media domain, Hutchby (2019), drawing on the notion of footing, proved that multimodal aspects of reported speech could be exploited in the process of managing the narrative relationship between a story teller, the story events, and the teller's footing itself; the data used was drawn from "the performative narrative context of a televised 'personal revelation' talk show" (Hutchby 2019: 1). Also, very recently, Choe (2020) has brought together Goffman's $(1974,1981)$ notions of footing, lamination, and frames, alongside other reconcilable concepts, in order to examine how different footings interact in a way that created "footing lamination" in the Korean livestream cats mukbang. The study identified four types of footing lamination, viz. (i) shifting footing as taking place with "reframing" and "rekeying," (ii) joint footing as occurring between "the host and the chat message participants to feed the cats," (iii) embedded footing as "created when the participants type to the cat as cat caregivers," and (iv) blended contrastive footings as transpiring when "the general frame of cats mukbang was interrupted by the dog and the cicada" (Choe 2020:77). 
Further, to the political domain the model of footing has been applied in the studies of Ensink (1997) and Cowper (2003). Ensink (1997) applied the concept of footing to the 1995 speech delivered by the Dutch Queen Beatrix to the Israeli Parliament, or the Knesset. Ensink focused on the use of pronouns as deictic formulations; and he found that their use was remarkably representative. Ensink's footing analysis of the speech demonstrated the Queen to be not only concerned about Israeli interests, but also about the Palestinian ones; this has been established through the Queen's control over her footing in addressing the Knesset: the Queen did not exhibit "a personal authority, but a symbolic and collective authority," with her "speaking in the name of the country" she represented (Ensink 1997:23). Cowper (2003) adopted Goffman's model of footing in analysing a politically satirical sketch performed by the interviewee John Bird and the interviewer John Fortune on 17 April 1997. Cowper's footing analysis revealed that the satirical strategies examined included "the inversion of appropriate political behaviour" in an election campaign; this has been effectively created through (i) depicting a politician "attacking members of his own party," (ii) displaying the politician's creation of "a dichotomy between the politicians and the electorate," and (iii) creating "paradoxes" in a way that rendered ironical meanings relevant in the given arguments (Cowper 2003:141-142).

In the coming section, I present the theoretical framework adopted in the current study; the framework takes the form of a pragmatically enhanced approach that integrates Goffman's interaction model of footing into speech act theory.

\section{Footing and speech acts interfaced: A pragmatically enhanced approach}

Goffman's (1981) definition of footing, as introduced earlier in the introduction (section 1), pays meticulous attention to the different roles assumed by speakers and hearers in social interaction. This has been enunciated in the premise that a shift in footing entails a shift in the "alignment" one takes up to oneself and any copresent other(s) in social interaction (strictly face-to-face); this is often expressed in the way one manages the production and perception of an utterance (Goffman 1981:128). Upon this premise, Goffman has offered a typology of the roles potentially associated with speakers and hearers, and preferred to use the term "audience" when describing the latter roles of hearers. Since the focus of the present context of research is speaker roles, the tripartite participation structure of speaker is presented. Speaking of the term "speaker," Goffman introduces the three notions of "animator," "author," and "principal," to describe what he calls the "production format' of an utterance" (Goffman 1981:145). Each of the three notions has been distinguished from the other as such: (i) animator is "the sounding box from which utterances come"; (ii) author is "the agent who puts together, composes, or scripts the lines that are uttered"; (iii) principal is "the party to whose position, stand, and belief the words attest" (1981:226). At this point, one may assume that speaker roles (animator, author, and principal) as well as any shifting in these roles must be pragmatically sensitive to the speech act(s) embedded in a given speech event. This 
is especially so, because the speaker participating in the speech event is likely to be involved in a twin-track process at utterance level: (i) animating or authoring the locution itself and simultaneously conveying a specific illocution related thereto; (ii) (re-)producing the speaker's perlocution in relation to any significant coparticipants. This aspect is made even clearer in the following account of speech act theory.

The theory of speech acts is often credited with John Austin's posthumous monograph How to Do Things with Words (1962). Counter to the philosophical tradition of logical positivism, Austin (1962) observed that a set of ordinarylanguage declarative sentences were resistant to the then-prevailing truthconditional analysis. He called this set performatives and distinguished them from describing statements, or constatives. According to Austin, whilst the latter can be verified as true or false, the former (performatives) are typically used to do things or perform acts, e.g., "I name this ship the Queen Elizabeth" and "I bet you sixpence it will rain tomorrow" (Austin 1962:5). Unlike constatives, Austin's performatives cannot be true or false; rather, in order to be felicitous, they must meet what Austin described as "felicity conditions" (Austin 1962:14-15). Indeed, later, Austin has extended the class of performative utterances to subsume constatives themselves as a special subclass of speech acts. As Levinson (1983) argues, towards proving this hypothesis, Austin offered three aspects of any speech act:

(i) locutionary act: the utterance of a sentence with determinate sense and reference

(ii) illocutionary act: the making of a statement, offer, promise, etc. in uttering a sentence, by virtue of the conventional force associated with it ...

(iii) perlocutionary act: the bringing about of effects on the audience by means of uttering the sentence, such effects being special to the circumstances of the utterance. (Levinson 1983:236, emphasis in original)

In his perceptive article (1976, reprinted in 1979), Searle opted to reason five basic (illocutionary) acts that can be performed in speaking. Table 1 exhibits Searle's terminology of such acts, alongside their technical definitions and the paradigm cases associated with each act. Crucially, Searle (1979) has introduced four felicity conditions (propositional-content, preparatory, sincerity, and essential) that apply to each type of the illocutionary acts exhibited in Table 1. As Searle argues, such conditions are necessary for "the successful and felicitous performance of the act" (Searle 1979:44).

Table 1. The basic categories of Searle's illocutionary acts (Source: Searle 1979:1215)

\begin{tabular}{|l|l|c|}
\hline \hline Illocutionary act & \multicolumn{1}{|c|}{ Technical definition } & Paradigm case \\
\hline \hline Representatives & $\begin{array}{l}\text { Committing the speaker to } \\
\text { something's being the case, to }\end{array}$ & Asserting and concluding \\
\hline
\end{tabular}




\begin{tabular}{|c|c|c|}
\hline & $\begin{array}{l}\text { the truth of the expressed } \\
\text { proposition. }\end{array}$ & \\
\hline Directives & $\begin{array}{l}\text { Being attempts by the speaker } \\
\text { to get the hearer to do } \\
\text { something. }\end{array}$ & $\begin{array}{l}\text { Requesting and } \\
\text { questioning }\end{array}$ \\
\hline Commissives & $\begin{array}{l}\text { Committing the speaker to } \\
\text { some future course of action. }\end{array}$ & $\begin{array}{l}\text { Offering, promising and } \\
\text { threatening }\end{array}$ \\
\hline Expressives & $\begin{array}{l}\text { Expressing the psychological } \\
\text { state about a state of affairs } \\
\text { specified in the propositional } \\
\text { content. }\end{array}$ & $\begin{array}{l}\text { Apologizing, thanking, } \\
\text { congratulating, } \\
\text { condoling, and } \\
\text { welcoming } \\
\end{array}$ \\
\hline Declarations & $\begin{array}{l}\text { Brining about some alteration } \\
\text { in the status or condition of the } \\
\text { referred to object or objects } \\
\text { solely in virtue of the fact that } \\
\text { the declaration has been } \\
\text { successfully performed. }\end{array}$ & $\begin{array}{l}\text { Declaring war, firing } \\
\text { from employment, } \\
\text { christening, and } \\
\text { excommunicating. }\end{array}$ \\
\hline
\end{tabular}

Further, as demonstrated in Table 2, Searle presents an example of a comparison between the class of directives (paradigm case of request) and that of commissives (paradigm case of promise) in terms of their felicity conditions. Indeed, while Searle's framework of speech acts is not the only account on offer (cf. Austin 1962; Bach and Harnish 1979), it is widely accepted and has continued to develop such that this framework is thought to lay bare certain insights about "the formal structure of language"; this can be substantiated in view of the fact that Searle has drawn heavily on his speech act theory in developing a closely parallel account of the "formal structure of intentionality" in a way that "has influenced a lot of reflection on propositional attitudes" (McKaughan 2012:89). This particular aspect renders Searle's account of speech acts helpful in revealing the "propositional attitudes" of the participants as well as their speech roles and footing shifts in given speech events.

Table 2. Searle's example of comparing the felicity conditions of request and warning (Source: Searle 1979:44)

\begin{tabular}{|l|l|l|}
\hline \hline \multicolumn{1}{|c|}{ Condition type } & \multicolumn{1}{|c|}{ Directive (Request) } & Commissive (Promise) \\
\hline \hline Preparatory condition & $H$ is able to perform $A$. & $\begin{array}{l}S \text { is able to perform } A . H \\
\text { wants } S \text { to perform } A .\end{array}$ \\
\hline Sincerity condition & $S$ wants H to do $A$. & $S$ intends to do $A$. \\
\hline $\begin{array}{l}\text { Propositional content } \\
\text { condition }\end{array}$ & $\begin{array}{l}S \text { predicates a future act } \\
A \text { of } H .\end{array}$ & $\begin{array}{l}S \text { predicates a future act } A \\
\text { of } S .\end{array}$ \\
\hline Essential condition & $\begin{array}{l}\text { Counts as an attempt by } \\
S \text { to get } H \text { to do } A .\end{array}$ & $\begin{array}{l}\text { Counts as the } \\
\text { undertaking by } S \text { of an } \\
\text { obligation to do } A .\end{array}$ \\
\hline
\end{tabular}


Now, having covered both theoretical accounts of footing and speech acts, I can safely revisit Goffman's (1981) model of footing by reinforcing its analytics with Searle's theory of speech acts and their felicity conditions, i.e., making explicit the potential acts performed in the participation framework in speech events. Apropos speaker roles, Goffman differentiates the three participants of animator, author, and principal in any speech event. Here, it should be clarified that the sociolinguist Dell Hymes (1972:56) has linked the concept of speech act to speech event as a "social unit" that "may consist of a single speech act, but will often comprise several." Hymes illustrates this link between speech event and speech act by offering the following scenario: "a party (speech situation), a conversation during the party (speech event), a joke within the conversation (speech act)" (Hymes 1972:56). Building on Hyme's argument, a speech utterance (or, speech act) may be regarded as the linguistic input embedded in a given speech event; and such a speech event may constitute a dialogic unit or conversation in discourse. Thus, participants and their roles in any dialogic unit can be recognized in the speech utterance/act itself. This may explain why both the model of footing and speech acts can be methodologically combined in explaining the participation framework in dialogic discourse; the point can be further discussed at the level of the three acts of meaning, locution, illocution, and perlocution, tackled above.

First, recognizing the locutionary acts produced by speakers should reveal their linguistic entities, i.e., nominally or referentially, in a way that brings out a whole set of nominations and/or pronouns; this can be technically labeled participation entities. Second, realizing the illocutionary acts performed by speakers should reveal their pragmatic identities, e.g., reporter, sympathizer, apologizer, threatener, or promiser, in a way that yields a whole nexus of performers; and this is the level of participation identities. Third, detecting the perlocutionary acts effected by the speakers should reveal their rhetorical/actional efficacy (i.e., the rhetorical or actional effect exercised by the speaker in an attempt to change the mind or the status of the target interlocutor) in a way that lays out a whole configuration of manipulators, or participation manipulators. Table 3 displays the potential correlation between the three facets of speech acts and the three aspects of footing, alongside the participation framework and the participants ensuing, in any speech event.

Table 3. Speech-act-based felicitous speaker roles

\begin{tabular}{|l|l|l|l|}
\hline \multicolumn{1}{|c|}{$\begin{array}{c}\text { Speech-act } \\
\text { facet }\end{array}$} & \multicolumn{1}{c|}{$\begin{array}{c}\text { Level of dialogic } \\
\text { representation }\end{array}$} & $\begin{array}{c}\text { Dialogic } \\
\text { realization }\end{array}$ & $\begin{array}{c}\text { Participant/Speaker } \\
\text { role }\end{array}$ \\
\hline \hline $\begin{array}{l}\text { Locutionary } \\
\text { act }\end{array}$ & Linguistic entity & Nominations & \pm Animator \\
\hline $\begin{array}{l}\text { Illocutionary } \\
\text { act }\end{array}$ & Pragmatic identity & Performers & \pm Author \\
\hline $\begin{array}{l}\text { Perlocutionary } \\
\text { act }\end{array}$ & $\begin{array}{l}\text { Rhetorical/Actional } \\
\text { efficacy }\end{array}$ & Manipulators & \pm Principal \\
\hline
\end{tabular}


From Table 3, each role of the speaker functions in a way that enacts the performance of the footing shifts running between interlocutors. However, notably, the above speech-act-based correspondences holding between the participants (speakers), their dialogic realization (nominations, performers, and manipulators), and the level of dialogic representation (linguistic entity, pragmatic identity, and rhetorical/actional efficacy) are completely data-driven; that is, such methodological correspondences are far from being static; they are highly dynamic and sensitive to the context of the current research data, with Allah and Iblis being the interlocutors in the dialogic interaction drawn from the Qur'an. Thus, perhaps with other sets of data from different sources and genres, these correspondences are likely to change. This should impart a great deal of methodological flexibility to the current pragmatically enhanced approach.

\section{Methodology}

The following subsections present two methodological aspects. First, subsection 1 introduces the term "Iblis" as being used in the Qur'anic context and the issue of data selection. Second, subsection 2 outlines the procedure followed in the study towards conducting the data analysis.

\subsection{Iblīs in the Qur'anic context and data selection}

The Qur'an uses the two terms Iblīs and Satan (Shaytān) to denote the same entity that stands as the symbol of disobedience to Allah. Öztürk (2009) gives an account of the etymology pertaining to the two terms. According to him, the word Iblis occurs in singular mode in all Qur'anic verses (eleven times), and it derives from “the verb 'iblas' [sic.], which means despairing and giving up of hope." On the nature of Iblīs, Saeed (2006) remarks that in the Qur'anic context, he (Iblīs) is presented as being "a jinn in origin but which somehow came to be associated with angels (Q18:50)" (Saeed 2006:43).

Indeed, the speech role of Iblīs derives its pragmatic significance in the target research data from his interaction with Allah as believed to be the divine author/source of the text (the Qur'an). As indicated earlier in the introduction, among the many dialogues running between Allah and Iblīs in the Qur'an, the one used here as the data for analysis (Q15:32-43) is accorded particular significance. This can be ascribed to the fact that its length and diversity of turns do provide fairly sufficient space for investigating a more-or-less full-scale participation framework with different footing shifts that are pragmatically performed in terms of illocutionary acts and their discursive effects throughout the verse-structured dialogue. The target Qur'anic interaction between Allah and Iblīs is exhibited in Table 4, with an Arabic transcript of the relevant verses as well as their transliteration and English translation.

\subsection{Procedure}

The current study follows a three-stage methodological procedure that is pragmatically enhanced in the footing analysis of research data. First, at locution level, the linguistic features and contents of the dialogic structure have been 
determined, e.g., (pro-) nominal references, verbal processes, mood, and markers of address. At this level all surface-structure features were taken as crucial clues to the significant participants in the speech event under analysis. Second, at illocution level, the pragmatic forces of the linguistically marked participants have been specified based on the context of each utterance made by these participants - Allah and Iblīs - and at this level the main concern was to explicate the potential interrelations between the participants performing the illocutionary acts and their speaker roles as either animators or authors, or both. Third, at the perlocution level, the effects of other related acts across the dialogic turns have been demarcated, and then analysed in terms of their rhetorical and/or actional efficacy in the overall speech event; at this level, the position of the participants was highlighted in a way that detected whether or not their speech role as principals materialized in the interaction; and this relied on whether those participants have attempted to manipulate other participants, and probably manage certain footing shifts in the speech event.

\section{Data analysis and discussion of results}

The target Qur'anic speech event tackled in the present analysis involves the dialogue between Allah and Iblīs (Q15:32-43) as falling in Chapter 15, which is known as sürat l-hij'r (roughly, if not reductively, translated as "The Rocky Tract"). As exhibited in Table 4, for analytic purposes, the dialogue is represented in three modes: (i) Classical-Arabic transcript as originally presented in the Qur'an, (ii) a transliteration of this Arabic transcript in the Roman alphabet, and (iii) an English translation of the verses composing the dialogue.

The first turn in the dialogue is initiated by Allah in the form of an

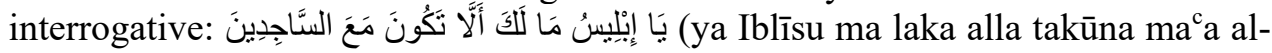
sājidīna ["O Iblīs! What is your reason for not being among those who prostrated themselves?"]) (Q15:32). On a priori grounds, the present interrogative cannot be reduced simply to one pragmatic function without further considering the overall context of the illocutionary force intended by the questioner, Allah; this is especially so should one allow for the assumption that interrogative sentences, in their locutionary forms, can "perform opposite functions such as affirmation and negation" (Fareh and Moussa 2008:155). But, here, with the current utterance, one of the essential locutionary features is the explicitly addressive vocative (ya Iblīsu ["O Iblīs"]) initiating the interrogative. It manifests the expressive function of the utterance as an interpellation directed at Iblīs, the addressee; and thus, at this point of opening the dialogue, the Qur'anic footing is divinely established in a way that sets up Allah's interactional alignment towards His interlocutor.

Contextually, this interrogative follows the event of Iblīs defying Allah's command to prostrate himself to Adam. Interestingly, the interrogative is projected from the saying verb قَالَ (qāla [said]), with the subject Allah standing as the reporter of His own utterance. At the locution level, the utterance is couched in the form of an interrogative, which is supposed to correspond to the illocutionary act of questioning the addressee or Iblīs; yet this act cannot pragmatically be construed as such since the Qur'an's conventional (theological) procedure entails that Allah be 
all-omniscient, and thereby being felicitously cognizant of the answer to the question on a posteriori grounds. Given this, the illocutionary act underlying such an utterance must be a rebuke, and thus constitute an expressive speech act. At this point, then, Allah is the explicit speaker who authored this act of rebuking Iblīs for his defiance. The essential condition of this speech act is its being an attempt by Allah to get Ibliss to realize his wrongdoing. Thereupon, the main speaker role of Allah is author; but He is also principal, whose reproaching stance against Iblīs can be detected through the illocutionary act performed dialogically by the author, Allah.

Table 4. Interaction of Allah and Iblīs in the Qur'anic text (Q15:32-43)

\begin{tabular}{|c|c|c|c|}
\hline Verse & Arabic transcript & Transliteration & $\begin{array}{c}\text { English } \\
\text { translation }\end{array}$ \\
\hline 32 & 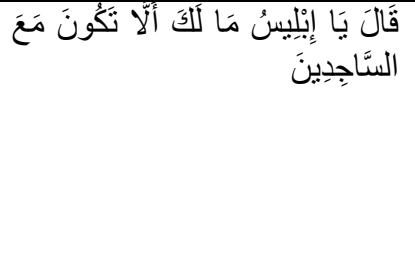 & $\begin{array}{l}\text { qāla ya Iblīsu ma laka } \\
\text { alla takūna ma }{ }^{c} a \text { al- } \\
\text { sājidīna }\end{array}$ & $\begin{array}{l}\text { (Allāh) said: "O } \\
\text { Iblīs! What is your } \\
\text { reason for not being } \\
\text { among those who } \\
\text { prostrated } \\
\text { themselves?" }\end{array}$ \\
\hline 33 & 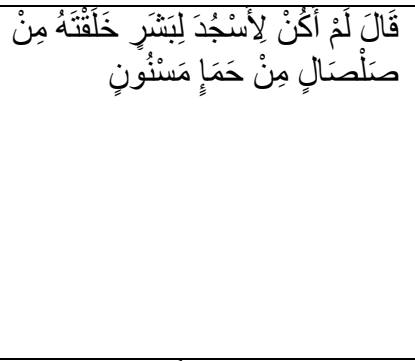 & $\begin{array}{l}\text { qāla lam akun li- } \\
\text { asjuda li-basharin } \\
\text { khalaqtahu min } \\
\text { șalșālin min hamarin } \\
\text { masnūn }\end{array}$ & $\begin{array}{l}\text { (Iblīs) said: "I am } \\
\text { not one to prostrate } \\
\text { myself to man, } \\
\text { whom Thou didst } \\
\text { create from } \\
\text { sounding clay, } \\
\text { from mud moulded } \\
\text { into shape." }\end{array}$ \\
\hline 34 & 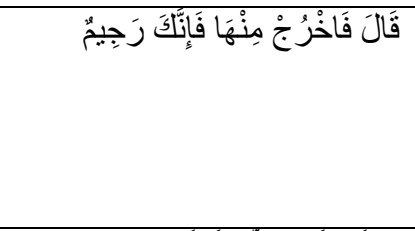 & $\begin{array}{l}\text { qāla fa-khruj minhā } \\
\text { fa-innaka rajī̄m }\end{array}$ & $\begin{array}{l}\text { (Allāh) said: "Then } \\
\text { get thee out from } \\
\text { here [Paradise]; for } \\
\text { thou art rejected, } \\
\text { accursed." }\end{array}$ \\
\hline 35 & 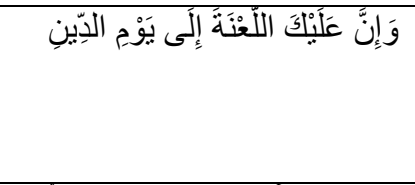 & $\begin{array}{l}\text { wa-inna calayka al- } \\
\text { lacnata ilá yawmi al- }^{\text {dīni }}\end{array}$ & $\begin{array}{l}\text { "And the curse } \\
\text { shall be on thee till } \\
\text { the day of } \\
\text { Judgment." }\end{array}$ \\
\hline 36 & 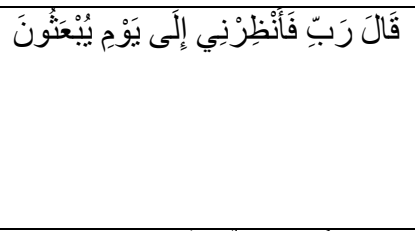 & $\begin{array}{l}\text { qāla rabi fa-anzirn̄̄ } \\
\text { ilá yawmi yub }{ }^{c} \text { athūna }\end{array}$ & $\begin{array}{l}\text { (Iblīs) said: "O my } \\
\text { Lord! Give me then } \\
\text { respite till the Day } \\
\text { the (dead) are } \\
\text { raised." }\end{array}$ \\
\hline 37 & 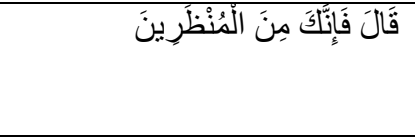 & $\begin{array}{l}\text { qāla fa-innaka mina } \\
\text { al-munz̧arīna }\end{array}$ & $\begin{array}{l}\text { (Allāh) said: } \\
\text { "Respite is granted } \\
\text { thee." }\end{array}$ \\
\hline
\end{tabular}




\begin{tabular}{|c|c|c|c|}
\hline 38 & 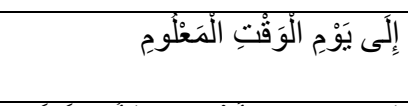 & $\begin{array}{l}\text { ilá yawmi al-waqti al- } \\
\text { mac'lūmi }\end{array}$ & $\begin{array}{l}\text { "Till the Day of the } \\
\text { Time appointed." }\end{array}$ \\
\hline 39 & 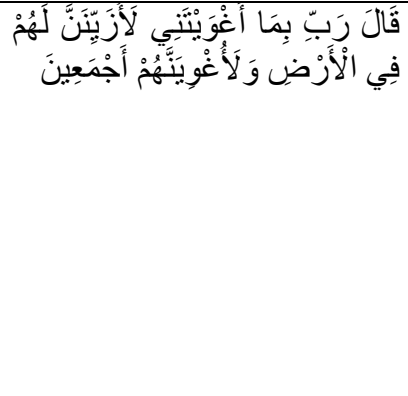 & 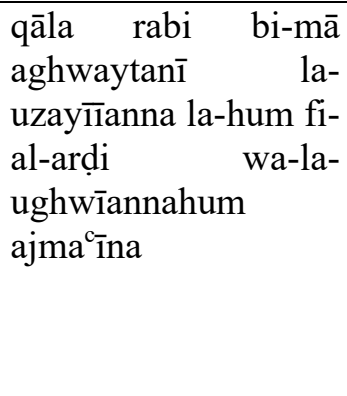 & $\begin{array}{l}\text { (Iblīs) said: "O my } \\
\text { Lord! Because } \\
\text { Thou hast put me in } \\
\text { the wrong, I will } \\
\text { make (wrong) fair- } \\
\text { seeming to them on } \\
\text { the earth, and I will } \\
\text { put them all in the } \\
\text { wrong." }\end{array}$ \\
\hline 40 & إِلاّ عِبَادَكَكَ مِنْهُمُ الَالمُخْلَصِينَ & $\begin{array}{l}\text { illā cibādaka min- } \\
\text { hum al-mukhlașīna }\end{array}$ & $\begin{array}{l}\text { "Except Thy } \\
\text { servants } \\
\text { [worshipers] } \\
\text { among them, } \\
\text { sincere and purified } \\
\text { (by Thy Grace)." }\end{array}$ \\
\hline 41 & 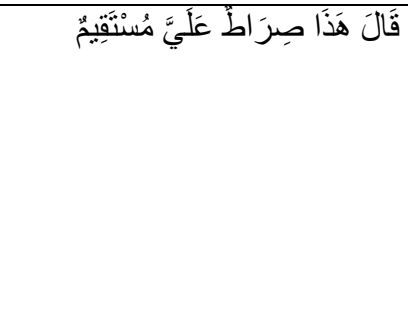 & $\begin{array}{l}\text { Qāla hādhā șirāṭun } \\
\text { calaya mustaqīmun }\end{array}$ & $\begin{array}{l}\text { (Allāh) said: "This } \\
\text { (way of My sincere } \\
\text { servants } \\
\text { [worshipers]) is } \\
\text { indeed a way that } \\
\text { leads straight to } \\
\text { Me." }\end{array}$ \\
\hline 42 & 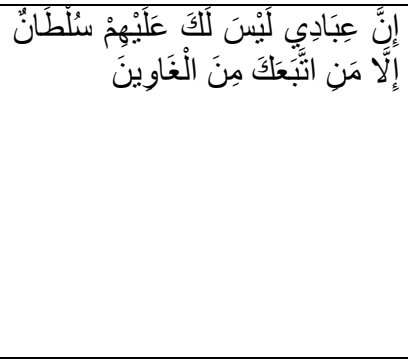 & $\begin{array}{l}\text { inna cibādī laysa la-ka } \\
{ }^{c} \text { alayhim sulțānun illā } \\
\text { mani tabacaka mina } \\
\text { al-ghāwīna }\end{array}$ & $\begin{array}{l}\text { "For over My } \\
\text { servants } \\
\text { [worshippers] no } \\
\text { authority shalt thou } \\
\text { have, except such } \\
\text { as put themselves } \\
\text { in the wrong and } \\
\text { follow thee." }\end{array}$ \\
\hline 43 & وَاِِنَّ جَهَنَّمَ لَمَوْ عِدُدهُهْ أُجْمَعِينَ & $\begin{array}{l}\text { wa-inna jahannama } \\
\text { la-mawcidu-hum } \\
\text { ajmacina }\end{array}$ & $\begin{array}{l}\text { "And verily, Hell is } \\
\text { the promised abode } \\
\text { for them all!" }\end{array}$ \\
\hline
\end{tabular}

In return to Allah's rhetorical question in verse 32, Iblīs produced the

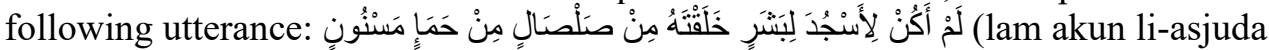
li-basharin khalaqtahu min ṣalșālin min ḥama?in masnūn ["I am not one to prostrate myself to man, whom Thou didst create from sounding clay, from mud moulded into shape."]) (Q15:33). The whole utterance can be regarded as a linguistic marker of the perlocution effected by Allah's foregoing question; and the utterance is again reported by Allah, yet the first-person "I" - presumed in the Arabic text and made explicit in the English translation - and the timeless present tense render the whole 
utterance the actual words of Iblīs. The current utterance stands as a direct answer to Allah's previous question; and thus it marks the perlocution of Allah's act of rebuke against Iblīs. Footing-wise, the alignment taken up by Iblīs towards Allah is deictically marked as a singular second-person pronoun that is agglutinated in the verbal expression خَ خَلَقَتَُّ (khalaqtahu ["Thou didst create"]), and translated as "Thou"; and this is the point where the dialogic structure of the utterance takes centre stage.

Further, Iblīs's current utterance represents the illocutionary act of an assertion, i.e., committing Iblīs to the truth that he is not to prostrate himself to a man, created from sounding clay or mud. Such an illocutionary act has been enacted by the essential felicity condition that this utterance counts as an attempt to get Allah to accept Iblīs's justification for not obeying His command. At this point, then, Iblīs is both author and principal of this assertion: first, his description (locution) of Adam as being created from mud; and second, his conviction that Adam is not worth prostration. Crucially, too, being the reporter of Iblīs's current utterance, Allah can be said to assume the speaker role of animator, i.e., voicing Iblīs's words in the Qu'anic text.

Iblīs's assertion constitutes a perlocutionary act that has dialogically

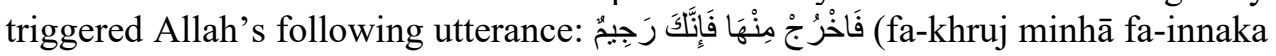
rajīm ["Then get thee out from here [Heaven/Paradise]; for thou art rejected, accursed."]) (Q15:34). At locutionary level, Allah's footing is set up through the imperative mood that is addressive in grammatical essence: the contextually presumed second-person pronoun in Arabic - translated as thee - in the imperative form reflects the divinely appellative or conative function in Allah's utterance, where it targets Iblīs as an interlocutor. At illocutionary level, the whole utterance is underlain by two consecutive acts: the first is a directive; the second is a

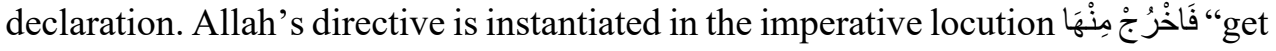
thee out from here [Heaven/Paradise]," as a divine command with the perlocution of Ibliss being forced out of Heaven or Paradise. Allah's declaration immediately follows the previous directive as the rationale for the command's perlocution: زَجِيٌّ "for thou art rejected, accursed." This illocutionary act of declaration is the explicit focus of Allah's stance towards Iblīs, and consequently the act marks off the former's speaker role as principal - a manipulator of the radical change of Iblīs's status.

It can be said that what renders the above perlocution felicitous are the three types of condition associated with Allah's directive: (i) the preparatory condition: Iblīs must do the act (by divine authority), (ii) the sincerity condition: Allah wants Iblīs to do the act, and (iii) propositional-content condition: Allah predicates the future act of Iblīs getting out of Heaven or Paradise. Allah's second act of declaration that Iblīs be rejected and accursed can be said to be the instantiation of the perlocutionary act of Iblīs's previous assertion (the act of justified defiance). The declaration act did change the status of Iblīs from being one of the angels who all prostrated themselves to Adam except for Iblīs - to being accursed and dismissed from Heaven, i.e., Paradise lost. Indeed, the main condition for, or sine qua non of, this declaration to be felicitous is preparatory, i.e., Allah is conventionally (theologically) able to do the act of declaring Iblīs to be accursed. 
With the above two acts performed by Allah in the dialogue, He assumes the two roles of author and principal: both acts, directive and declaration, are divinely issued and addressed directly to Iblīs. But, crucially, Allah also takes on the role of animator since the two acts have been reported by Him through the verbal process قَالَ (qāla [said]), which means Allah brings His own voice in the Qur'anic text. At this point, it should be noted that, being the principal whose position is forced and declared with efficacy, Allah can be described as a manipulator at this point of the speech event, i.e., manipulating the status of Iblīs.

Indeed, the same act of declaration continues with Allah's utterance وَإِنَّ عَلَيْكَ (wa-inna calayka al-lacnata ilá yawmi al-dīni [“And the curse shall be on thee till the Day of Judgment.”]) (Q15:35), which immediately follows in the dialogue and extends the perlocutionary effect of Iblīs's act of defiance. Thus, the footing associated with Allah remains the same - being author, animator, and principal - and his manipulating status is further reinforced with the act of declaration affirming Iblīs's new status of being accursed and ousted from Heaven, and thereby losing Paradise. Interestingly, at locution level, this footing aspect of speaker roles has been deictically marked by the second-person pronoun thee as

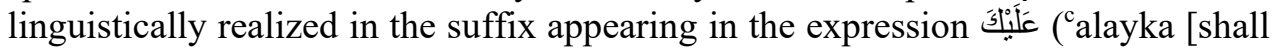
be on thee]), which marks the participation framework in the utterance and sets up Allah's alignment towards Iblìs as a direct addressee.

The next turn in the dialogue is produced by Iblīs as a perlocutionary effect that has been triggered with Allah's previous acts of declaration. This turn has the

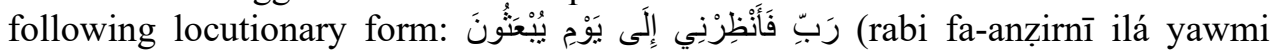
yubcathūna ["O my Lord! Give me then respite till the Day the (dead) are raised."]) (Q15:36). Again, while standing as the actual words of Iblīs, these words have been animated by Allah as the reporter of the whole utterance. As such, it can be said that Allah has voiced Iblīs's current request as an illocutionary act of directive. A number of felicity conditions may well apply to this directive: (i) Allah is able to perform the act of giving Iblīs respite till the Day the dead are raised, (ii) Iblīs wants Allah to do this act, and finally (iii) the act is an attempt by Iblis to get Allah to do the act. All three felicity conditions render the act a happy directive in a way that highlights the speaker roles of Iblīs as author and principal. The role of author is enacted by Iblīs as a performer of the act of request from Allah, and the role of principal is endorsed by Iblīs as a manipulator who makes explicit his position of aspiring to be given respite till the Day of Judgment.

The efficacy of Iblīs's preceding request has worked out well with the next

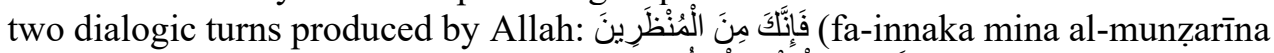

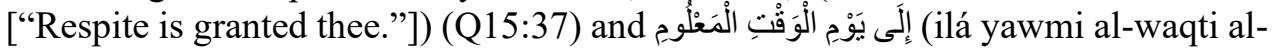
maclūmi ["Till the Day of the Time appointed."]) (Q15:38). Again, the first turn exposes the locutionary feature of the second-person thee - appearing as a suffix in the expression فَإنَّكَ (fa-innaka [thee]) - which deictically marks Allah's footing towards Iblīs in the verse's participation framework. However, taken together, the two turns constitute one utterance that carries the illocutionary act of declaration; it has been made under the preparatory felicity condition of Allah being theologically able to do the act demanded by Iblīs in the above utterance. At this point, then, 
Allah's footing is shaped by His three speaker roles of author, animator, and principal - the first being the performer of the act of declaration itself, the second being the reporter of His own declaration through the verb said (qāla), and the last being the manipulator of Iblīs's fate.

Having received Allah's acceptance of his request, Iblīs made the following

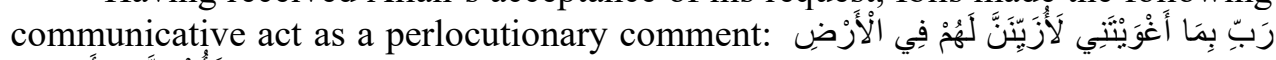

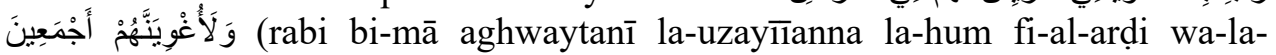
ughwīannahum ajma īna ["O my Lord! Because Thou hast put me in the wrong, I will make (wrong) fair-seeming to them on the earth, and I will put them all in the wrong."]) (Q15:39). Here, at locution level, Iblīs's footing is marked by the vocative (rabi/“O my Lord”) which directly positions Allah in the participation framework of being an addressee, and thereby placing Him on the receiving-end of the dialogue. Of course, the whole locution has been reported by Allah Who uses the same verb of saying. It follows then that Allah is the animator of Iblis's actual words. With these words, Iblīs performs a commissive, where he vows to make wrong fair-seeming to Adam's offspring on the earth and consequentially put them in the wrong. The act has been performed felicitously under the following conditions: (i) Iblīs is able to perform such an act, (ii) he intends to do this act, and essentially (iii) the utterance counts as an undertaking by Iblīs of an obligation to do the act. So, here, at this point of the dialogue, Iblīs is not only author (or performer) of the utterance, but he is also principal with a specific task (if not lifetime duty): putting Adam's offspring in the wrong. This affords Iblīs an amply dialogical space for acting as a manipulator of the whole situation - potentially manipulating the status of some of Adam's offspring till the Day of Judgement.

Following the above commissive is Iblīs's concluding utterance that his aforementioned vow excludes Allah's servants/worshipers who are sincere and

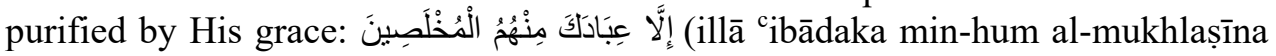
["Except Thy servants [worshipers] among them, sincere and purified (by Thy Grace)."]) (Q15:40). The locutionary level of the deictic realization of the secondperson pronoun suffixed in the expression عِبَادَك (Thy) reinforces the participation framework wherein Allah is directly addressed by Iblīs. Only at this point of the dialogue does an utterance reflect Iblīs's alignment towards Allah and His sincere servants/worshipers in the whole speech event. Further, illocution-wise, the whole utterance proceeds with Iblīs's commissive act or vow indicated earlier above. Being the message author and principal, Iblīs does not only perform the act but he also reflects his position in relation to those who serve or worship Allah sincerely and are purified by Him: Iblīs would not be able to perform his earlier commissive (vow) onto them. Certainly, this amounts to a limitation to Iblīs's dialogic role as a manipulator; in other words, he is not presented as a full-scale seducer of Adam's off-spring.

In reaction to Iblīs's commissive above, Allah took the floor with a counter-

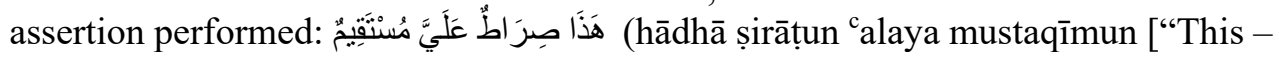
way of My sincere servants [worshipers] - is indeed a way that leads straight to Me.”]) (Q15:41). With this assertion, Allah commits Himself to the truth of a propositional content that coheres with Iblīs's earlier commissive. Thus, here, Allah 
reacts to the position of Iblīs as principal by revealing the former's position in relation to the sincere servants/worshipers who follow the path leading straight to Him. Of course, the assertion is felicitous in view of the theological postulate that Allah is absolutely able to perform the act represented. This renders Allah author of a message that is also animated by His well-established role as a reporter of His speech act.

The dialogue closes with two consequent acts performed by Allah, one is assertion and the other is commissive or specifically a threat. As regards the

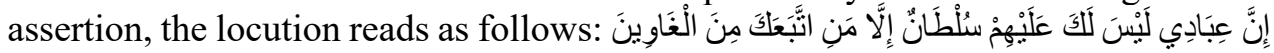
(inna cibādī laysa la-ka calayhim sulțānun illā mani tabacaka mina al-ghāwīna ["For over My servants [worshipers] no authority shalt thou have, except such as put themselves in the wrong and follow thee."]) (Q15:42). Here, Allah performs an assertion about the different status between His sincere servants/worshipers and those who would be following Iblis and consequently be put in the wrong; this closely relates to the earlier position of Iblīs as principal in the participation framework of the dialogue. As discussed above, in his own commissive (Q15:39, 40), Iblīs made his position explicit by vowing to put all of Adam's offspring in the wrong except for those who would sincerely serve/worship Allah. Thus, at this point, through the current assertive act performed by Allah, Iblīs's position has become contextually felicitous. Allah's speaker role as author has already been equally performed, and this can be observed in the grammatical structure of the locution itself: using the first-person possessive determiner with a nomination in عَبَادِي ('ibādī [My servants/worshipers]) entails the endophoric (i.e., in-text) presence of Allah. Further, this speech role of the divine author has had its perlocutionary effect: validating Iblīs's position in the present speech event, and thereby featuring his speech role as principal. Here, it can be said that such an author-principal sequence highlights Allah's dialogic footing towards Iblīs and his potential followers.

Coming to the final utterance made by Allah in the whole speech event, there can be no doubt that it has the illocutionary force of a threat: وَإنَّ جَهَنََّ لَمَو عِدُهُمْ أَجْمَِِينَ (wa-inna jahannama la-maw cidu-hum ajma īna ["And verily, Hell is the promised abode for them all!']) (Q15:43). The present act has the strictly conventional/theological felicity conditions of a commissive: (i) Allah is able to do the act of sending both Iblīs and all those who would follow him to Hell, (ii) Allah intends to do such an act, (iii) Allah predicates this future act of Himself, and (iv) the commissive counts as the undertaking by Allah of an obligation to do the act. Here, accentuating His footing towards Iblīs and his followers, Allah is both the author who performs the threatening act and the principal whose position is made explicit and addressed to Iblīs and those followers. Crucially, with this footing shift, Allah can be said to have changed the alignment He takes up from His sincere servants/worshipers on the one hand to Iblīs and his followers on the other. Even more crucially, this divine shift in footing has been marked by Allah performing an illocutionary shift from the representative act of assertion to the commissive act of threatening. Eventually, with divine illocutionary footing shift, Allah presents Himself as a manipulator who controls the overall situational context, mainly by 
deciding on the participants who would be doomed to Hell and those who would stay away from it.

Thus, having presented the foregoing pragmatically enhanced analysis, it can be said that the footing shifts from one participant to another have been grounded in the different speech acts produced and reacted to by Allah and Iblīs. To begin, Allah has uttered certain locutionary features that target Iblīs as an addressee: (i) the vocative يَا بِيْلِيس (O Ibliss) opening the speech event (Q15:32), (ii) the pronominal deictics of thee (Q15:34, 35, 37) and thou (Q15:42) referring to Iblīs, and (iii) the imperative form addressed to Iblīs (Q15:34). Further, Allah has performed four types of theologically felicitous acts with certain effects on the addressee, Iblis: expressive (rebuke) (Q15:32), directive (command) (Q15:34), declaration (Q15:34, $35,37,38,41,42)$ and commissive (threat) $(\mathrm{Q} 15: 43)$. Interestingly, with all four acts performed, Allah has consistently taken on the roles of author and animator: the former being the actual performer of the illocutionary act itself, and the latter a reporter of such a performed act. This has afforded Allah the discursive position of being a reporter of His own words or voice in the speech event; in other words, the position of animating his speaker role as author. Equally important, Allah's performed (authored) and reported (animated) acts have had their pragmatic effect (perlocution) in such a way that has demonstrated His stance towards Iblīs and his would-be followers as well as His sincere servants/worshipers; with this stance made explicit, Allah's role as principal has proved efficacious, particularly in view of the theologically procedural felicity conditions of such performed and reported acts.

Regarding the second interlocutor, Iblīs, his locutionary features target Allah as an immediate addressee: (i) the vocative $($ O my Lord!) $(\mathrm{Q} 15: 36,39)$, (ii) the deictic markers of Thou (Q15:33) and Thy (Q15:40) directly referring to Allah, and (iii) the imperative form addressed to Allah (Q15:36). Further, Iblīs has performed three types of theologically felicitous acts with certain effects on the addressee, Allah: assertive (Q15:33), directive (request) (Q15:36), and commissive (vow) (Q15:39, 40). Being the actual performer of these acts, Iblīs has assumed the role of author, whose most utterances have been animated by Allah as the manifest reporter of such utterances. Indeed, one may well assume that Allah's role as animator of Iblīs's utterances is itself constituted by the speech act of reporting; such a speaker role of animator is part of the typically Qur'anic reportorial acts performed by Allah Who presents virtually all the voices brought in the Qur'an. Significantly, too, Iblīs's performed (authored) acts - and animated by Allah - have had their perlocutionary effect in a way that overtly exhibits his position in relation to Allah and His sincere servants/worshipers as well as to those who would be seduced by Iblīs himself; and at this point, Iblīs qua principal has become efficacious, especially under the theologically procedural felicity conditions of both Iblīs's role as author and Allah's as animator.

\section{Conclusion}

Now, it has become clear that the speaker roles of animator, author, and principal can readily be recognized as being performers of the different illocutionary acts in 
the main Qur'anic dialogue between Allah and Iblīs (Q15:32-43). These roles, along with their concomitant acts, have orchestrated the footing shifts made by Allah and Iblīs towards each other and towards any other non-participating referents in their dialogic encounter. This has been proved by methodologically interfacing Goffman's (1981) model of footing and Searle's (1976) theory of speech acts in a way that reveals how the illocutionary acts performed by Allah and Iblīs assume their dialogic participation framework at the utterance level of speech production and reception in the dialogue.

The analysis conducted on the speech acts performed in the dialogue has been predicated on the hypothesis that speaker roles as identified by Goffman are Qur'anically instantiated at the level of three acts of meaning. First, at the level of locutionary acts, these roles have materialized in a number of linguistic forms: (i) (pro-) nominal forms, including Iblīs, I, my, thou, and thee. This is where the notion of linguistic entities has been usefully utilized as textual elements with welldefined syntactic categories in the dialogue, but their speaker roles as authors or animators still seemed to be hazy. Second, with illocutionary acts, the roles have become performers of certain acts, e.g., assertions, commissives, directives, and declarations; and dominantly these performers have tended to be authors and/or animators in the speech event. At this point, the notion of pragmatic identities has been effectively employed as contextual elements with specific semantic links holding between speaker and hearer across the different turns (verses) in the overall dialogue. Third, through perlocutionary acts, the acts performed by authors and/or animators have produced effect on the speech-event participants; this effect has been traced in the reactionary discursive positions taken up by the speakers themselves. Likewise, this is the point where the notion of rhetorical/actional efficacy has been adopted in a way that explains the stance of the performers, and their speaker roles, who proved to be manipulators of certain situations in the speech event.

For future research, the same method of integrating footing into the larger framework of speech act theory needs to be applied to other types of genres and/or different sets of data. This should afford Goffman's interaction model of footing more pragmatic flexibility of analysis; and thus it can open up new horizons for analysing participation framework in dialogic discourse at large.

Amir H. Y. Salama

Prince Sattam Bin Abdulaziz University, Saudi Arabia

Kafr El-Sheikh University, Egypt

ORCID Number: 0000-0001-9320-558X

Email: amir.salama79@gmail.com 


\section{References}

Al-Ājurrī, Abū Bakr M. (1983). Al-Sharī'a. Beirut: Dār al-kutub al- 'Ilmiyya:

Abdul-Raof, Hussein. (2001). Qur'an Translation: Discourse, Texture and Exegesis. London: Routledge.

Abdul-Raof, Hussein. (2018). New Horizons in Qur'anic Linguistics: A Syntactic, Semantic and Stylistic Analysis. London: Routledge.

Abrahamov, Binyamin. (2006). Theology. In A. Rippin (ed.), The Blackwell Companion to the Qur'ān, 420-433. Oxford: Blackwell Publishing.

Ali, Yusuf. (1983/1934). The Holy Qur'an: Text, Translation, and Commentary. Maryland: Amana Corp.

Austin, John L. (1962). How to Do Things with Words. Oxford: Clarendon Press.

Bach, Kent and Robert Harnish. (1979). Linguistic Communication and Speech Acts. Cambridge, MA: MIT Press.

Čekaitè, Asta and Ann-Carita Evaldsson. (2019). 'Stance and footing in children's multilingual play: Rescaling practices in a Swedish preschool'. Journal of Pragmatics, 144: 127-140. https://doi.org/10.1016/j.pragma.2017.11.011

Choe, Hanwool. 'Talking the cat: Footing lamination in a Korean livestream of cats mukbang'. Journal of Pragmatics, 160: 60-79. https://doi.org/10.1016/j.pragma.2020.02.009

Clayman, Steven. E. (1992). 'Footing in the achievement of neutrality: The case of news-interview discourse'. In Drew, P. and J. Heritage (eds.), Talk at Work: Interaction in Institutional Settings, 163-198. Cambridge: Cambridge University Press.

Cowper, Janet. (2003). 'Footing, framing and the format sketch: Strategies in political satire'. In Ensink, T. and C. Sauer (eds.), Framing and Perspectivising in Discourse, 109-145. Amsterdam: John Benjamins.

Fareh, Shehdeh and Maher Bin Moussa. (2008). 'Pragmatic functions of interrogative sentences in English: A corpus-based study'. International Journal of Arabic-English Studies (IJAES), 9: 145-164. ijaes.net/article/fulltext $/$ view? volume $=9$ \&issue $=1 \&$ id $=8$

Goffman, Erving. (1974). Frame Analysis. New York: Harper \& Row.

Goffman, Erving. (1979). 'Footing'. Semiotica, 25 (1-2): 1-29. https://doi.org/10.1515/semi.1979.25.1-2.1

Goffman, Erving. (1981). Forms of Talk. Oxford: Blackwell.

Hutchby, Ian. (2019). 'Performed retelling: Self-enactment and the dramatisation of narrative on television talk show'. Journal of Pragmatics, 149: 1-13. https://doi.org/10.1016/j.pragma.2019.05.026

Hymes, Dell. (1972). Model of the interaction of language and social life. In Gumperz, John J. and Dell Hymes (eds.), Directions in Sociolinguistics: The Ethnography of Communication, 35-71. New York: Holt, Reinhart and Winston. 
Kristiansen, Elisabeth D. (2017). 'Doing formulating: "Writing Aloud Voice" sequences as an interactional method'. Journal of Pragmatics, 114: 49-65. shttps://doi.org/10.1016/j.pragma.2017.04.002

Levinson, Stephen C. (1983). Pragmatics. Cambridge: Cambridge University Press.

Levinson, Stephen C. (1988). 'Putting linguistics on a proper footing: Explorations in Goffman's concepts of participation'. In Drew, P. and A. Wootton (eds.), Erving Goffman: Exploring the Interaction Order, 161-227. Cambridge: Polity Press.

McKaughan, Daniel J. (2012). 'Speech acts, attitudes, and scientific practice: Can Searle handle "Assuming for the sake of Hypothesis"?'. Pragmatics \& Cognition, 20 (1): 88-106. https://doi.org/10.1075/pc.20.1.04mck

Öztürk, M. (2009). 'The tragic story of Iblis (Satan) in the Qur'an'. Journal of Islamic Research, 2 (2): 128-144.

Partington, Alan. (2003). The Linguistics of Political Argument: The Spin-Doctor and Wolf-Pack at the White House. London: Routledge.

Saeed, Abdullah. (2006). 'Contextualizing'. In Rippin, A. (ed.), The Blackwell Companion to the Qur'ān, 36-50. Blackwell Publishing.

Sandrelli, Annalisa. (2017). 'Simultaneous dialogue interpreting: Coordinating interaction in interpreter-mediated football press conferences'. Journal of Pragmatics, 107: 178-194. https://doi.org/10.1016/j.pragma.2016.05.011

Searle, John R. (1976). 'The classification of illocutionary acts'. Language in Society, 5: 1-24. https://doi.org/10.1017/S0047404500006837

Searle, John R. (1979). Expression and Meaning: Studies in the Theory of Speech Acts. Cambridge: Cambridge University Press.

Shannon, Claude E. and Warren Weaver (1949). The Mathematical Theory of Communication. Urbana: University of Illinois Press.

Wortham, Stanton E. F. (1996). 'Mapping participant deictics: A technique for discovering speakers' footing'. Journal of Pragmatics, 25: 331-348. https://doi.org/10.1016/0378-2166(94)00100-6 